\title{
Autobiographical Writings by Portuguese Emigrants in Newark: Glocal Emancipation and Resisting Stereotypes
}

\author{
ELSA LECHNER \\ Universidade de Coimbra
}

\begin{abstract}
This article examines the experience of Portuguese immigrants in Newark, NJ (USA) through the analysis of autobiographical writings. It aims to highlight the heuristic value and social relevance of autobiographical writings by focusing on four Portuguese immigrants in Newark who self-published their life stories. I argue that autobiographical essays serve as a form of self-valued expression in defiance of the stereotypes that associate the Portuguese immigrant with low levels of education and a lack of interest in literature and culture in general. Finally, I underscore the contribution of biographical research in the emancipation of undervalued groups and individuals.
\end{abstract}

Keywords: Portuguese immigration; diaspora; stigma; resistance; authorship

Autobiographical writing belongs to a literary genre that has different uses and connotations depending on the context in which it is produced and published. ${ }^{1}$

\footnotetext{
${ }^{1}$ I would like to thank Professors Onésimo Teotónio de Almeida, Francisco Fagundes, Michèle Koven, Kimberly Da Costa Holton, and my colleagues Diana Andringa and Carlos Nolasco for their comments on a Portuguese version of this text earlier presented at the VI International Congress on (Auto)Biographical Research, UERJ, Rio de Janeiro, November 2014. This project was funded by the Fulbright Commission/Instituto Camões and hosted by the Department of Portuguese and Brazilian Studies, Brown University,
} 
The autobiographical texts of the Portuguese who reside in the American state of New Jersey exemplify a synthesis, or cultural hybrid, that emerges out of a wellestablished and accepted literary genre in that country (Lee). They stand out as significant particularly due to the scarcity of autobiographical works by Iberian authors (Medeiros and Herpoel), but also because of the social origin of their writers and the negative image associated with the "figure" of the Portuguese emigrant in general. ${ }^{2}$

The texts I have chosen were written by first-generation immigrants with little formal education who arrived in the US from Portugal between 1950 and 1980. Given these conditions, the texts transcend the category of ethnoautobiographies (Browder; Lechner, "Enfants de l'Eau"), representing an exercise in emancipation. They empower the stereotyped and stigmatized members of a class who make more or less conscious use of their identity as a biopolitical instrument (Fagundes; Villar). While my own anthropological understanding of empowerment certainly differs from that employed by these authors, the very act of writing and publishing an autobiography represents here a form of resistance to the negative image associated with illiteracy, poverty, invisibility, and a lack of any kind of power in both private and public spheres. Also, considering that in a published autobiography there is an implicit contract between the author and his or her potential readers (Lejeune), these books bring to the Portuguese diasporic scenes (in Portuguese) the opportunity of an infrequent (not to say rare) pact between Portuguese emigrant authors and Portuguese readers. Empowerment, in this sense, is analyzed as a double-effect around the publication of Portuguese emigrant memoirs or autobiographies: the authors embody a traditional genre thrust out from the Iberian world, and the readers have the chance to witness and be inspired by such boldness. At the same time, Portuguese readers, both in Portugal and the diasporic communities, are

and the Department of Spanish and Portuguese, Rutgers University, under the 2013 Fulbright Program for $\mathrm{PhD}$ researchers and professors.

${ }^{2}$ Many of those that I interviewed expressed a dislike regarding the term "emigrant." As they see it, this is a discursive and administrative/political designation that does not fit them. They see themselves as "Portuguese residents overseas," and consider the category "emigrant" to be an instrument of exclusion foisted upon them by those who never had to leave Portugal. 
exposed to a different version of a common narrative: that of the old and vast saga of Portuguese emigration.

My proposed analysis focuses specifically on the autobiographical writings of two Portuguese men and two women in the US whom I contacted during fieldwork throughout the year 2014: José António (Jo) dos Santos, Felicidade Almeida, António José (Tozé) Silva, and Ilda Pinto de Almeida. ${ }^{3}$ All four spontaneously offered their books to me during the course of my fieldwork in Newark. Other Portuguese residents in New Jersey have written autobiographical texts and books that could also be considered in this analysis, but these four were chosen as examples of a form of self-presentation that explicitly engages in resistance to and emancipation from stereotypes and clichés circulating in Portugal and its diaspora communities. In this regard, it must be noted that the figure of the emigrant is one of the "key symbols" of Portuguese national identity (Brettell), one that has frequently been stigmatized. As Kimberly DaCosta Holton has argued: "anthropologists of Portuguese migration have attributed the emigrant's stigma to restrictive immigration policies during the Estado Novo, to a cycle of 'illusion' perpetuated by returning emigrants who misrepresent their wealth . . ., to 'inveja'. . , and a sense of betrayal among those left at home" (92). The work of Michèle Koven also seems relevant in this respect, as it analyzes those associated with Portuguese emigration contesting dominant beliefs and/or images about themselves. Such self-esteem among the Portuguese is gaining terrain only recently, both at home and within diasporic communities.

In a sense, the autobiographical works that I examine in the present article are anything but typical. In the current political context, characterized by the renewal or intensification of a long history of Portuguese emigration, its analysis serves as evidence of the decisive contribution made by biographical research to the empowerment of groups and individuals undervalued in the dominant Portuguese discourse and in everyday perceptions.

\section{Times and Places: From Social Constraints to Self-Reinvention}

\footnotetext{
3 Jo Santos composed his autobiography in collaboration with Baldomiro Soares, and the resulting book was published under the latter's name. Felicidade Almeida's text was amply revised by João Martins.
} 
The four works chosen for analysis were written by two men and two women who left continental Portugal for New Jersey at different times: Felicidade Almeida left Portugal in 1956 and Jo Santos in 1973, while Ilda Pinto de Almeida and Tozé Silva both left in 1986. Felicidade Almeida was born in Murtosa, Aveiro (Newark's sister city), and she died shortly after the publication of her book, at over 80 years of age. José dos Santos was born in Freixiosa, Mangualde, while Ilda Pinto de Almeida came from the district of Viseu. Tozé Silva was born in the village of Currelos, also in the district of Viseu.

Felicidade Almeida's book was offered to me by its editor, João Martins, a poet and wood sculptor whom Ms. Almeida had asked to help with the manuscript. The others were given to me by their authors. Both Felicidade Almeida and Ilda Pinto de Almeida's books have titles that refer to the notion of time, while the books by Tozé Silva's and Jo Santos's have titles that reflect a concern with the notion of space. Each of the four books describe the personal journey of its author, starting with birthplace, family, and childhood before documenting travels to other destinations during the period of the Estado Novo (France, Switzerland, the former African colonies), and culminating in arrival to the United States.

Space and time are privileged loci of analysis in autobiographical texts. As existential measures of each reported life, time and space serve as factual and psychological references in the storyteller's narration, while guiding the text's autobiographical identity, which can be understood as a historical, cultural artifact. In the case of these works, written by migrant authors, the references acquire an even greater significance since their life experiences are, by definition, definitively marked by geographical rupture and the temporalities of emigration. As Sidonie Smith and Julia Watson observe, the autobiographical subjects and subjectivities transmitted by autobiographical texts become understandable in the light of key concepts such as memory, experience, identity, space, body, and agency (21-22). Memory refers to time but also to times with historic meaning, times which attribute new or familiar meanings or contexts of meaning to the politics of memory, not to mention collective and private legends of the past. In this sense, private reflections narrated in the first person refer to memory and time as expressions of concrete experiences or as related to experience. Memory is constitutive of subjects and subjectivities, but it is also a form of interpretation, of authorship, tradition, and creativity that may reveal different appropriations of 
a collective past. The very fact that a migrant brings to light his or her own perspective on history represents an exercise in freedom contrasting preexistent and dominant social representations (Lechner, "Migração").

Being both lived and inherited, the narrated life is a way of communicating identity, and the very narratives produced to account for life experiences are themselves what Paul Ricoeur referred to as "narrative identities." Biographical accounts are discursively and hence ideologically positioned, whether as a consciously creative text or not. They are culturally and historically specific; and since the current contexts of transcontinental migrations challenge the specific and the local in a global sense (or, at least, through their mobility), the life stories of migrants challenge the actual concept of local, transforming it into a glocal space of analysis. The local in the global, as well as the global in the local serve to frame the mobile existences and identities of men, women, and children on the move between countries, cultures, languages and histories (Robertson; Bauman; Bahbha).

In the contemporary context, space is not only what is occupied by the body, bringing identity to geographical territories; it is also a place associated with relations, exchange, dialogue and confrontation, geopolitics, inventiveness, interiority and exteriority, adaptation, and the reinvention of senses of belonging. In previous work, I have developed an analysis of space and sense of belonging drawing from the life story of António Cravo, a Portuguese emigrant residing in France (Lechner, "Subjectivity," "Para deixar"). Cravo first wrote the story of his life in one single poem that follows the five names he actually had along his biography. The names are those of the little abandoned child in his native village, the poor youngster living with the gypsies, the young adult going to the capital, the Portuguese public worker in France, and the poet and the writer living between France and Portugal.

In such disrupted lives, one may find agency and the negotiation of meanings, or the capacity of migrants to act and create in ways that undermine stereotypes, regardless of the migrants' rural origins. Theories of agency (Smith and Watson) refer to various notions of the subject and subjectivities, but the main concern in our analysis in this regard focuses on the (trans)formative action of the subjects on their own lives, beginning with "technologies of self" (Foucault) and an understanding of their life contexts through autobiographical accounts. "A força de um lugar," a poem by Ilda Pinto de Almeida, expresses 
these various elements: memory, space, body, experience, time, identity, and agency:

Recordar a minha terra

É dar vida ao pensamento

É relembrar a serra

E esquecer o sofrimento

Quando era catraia

Queria uma estrela ser

Para dar à poesia

Brilho ao anoitecer

Pensar na casa onde cresci

Era recordar como trepei a oliveira

Em seus ramos fui cantadeira

Das poesias que na mente eu escrevi. (56)

When asked about the motives for publishing their memories and autobiographical reflections, authors mostly refer to the idea of transmission among their families and community. Such intention leads to a time and space of public affirmation and socialization of the value they attribute to their own experience and identity. This is an important fact that underscores the empowering consequences of autobiographical works by common people. And much more so when we know that we are dealing with emigrants forced to leave Portugal to escape poverty and low levels of education, only to encounter a life of much sacrifice and work in low-skilled jobs. ${ }^{4}$ The lives of the many emigrants

\footnotetext{
${ }^{4}$ The socio-economic profile of twentieth-century Portuguese emigration is well known. Statistical data, and historiographic work about the fluxes to Brazil, central and northern Europe, the US, Canada, South Africa, Venezuela, among other destinations, attest the general characteristics of a mainly rural population, with very low levels of education, low-skilled jobs, mainly Catholic, mainly politically disengaged or indifferent. The very same characteristics are found in the Portuguese community of New Jersey with one extra particularity: the important presence of retornados, or Portuguese from the ex-colonies who had to leave in extremis during the decolonization process, and who did not feel
} 
that Portugal evicted represent a silent heritage that actually could bring a valuable contribution to Portuguese history, culture, and society. They are "submersed biographies" (Cattarulla) not usually well recognized but that do constitute an invaluable legacy both to diasporic communities, the country of origin, and the world in the era of migrations.

In a published study of three biographies of Azoreans in North America, Villar analyses the autobiographical works as a site for performative empowerment, in terms of culture and identity for these immigrants or descendants of Portuguese immigrants from the Azores living in the USA (244). Writing, in such cases, becomes a bridge between two world views, two experiences and two identities. It is also an affirmation of a unified, yet mixed identity, made up of the individual's sense of belonging to two different places: here and there, Portugal and the USA.

Felicidade Almeida reveals that her reason for passing her life story on to her grandchildren was to leave a message "para que nunca percam a esperança, nem deixem de sonhar" (5). Her story is a difficult one of childhood poverty, family abuse, and lone immigration in 1956, at 26 years of age. Hers was a migratory experience marked by a marriage of convenience so that she could remain in the US, a story of much suffering, loneliness, family betrayal, sickness, and a great deal of hard work and sacrifice.

Ilda Pinto de Almeida also indicates a desire to communicate to her readers that one can overcome obstacles no matter how difficult it may seem. Ilda moved with her husband and daughter first to Switzerland, where she lived for three years (from the age of 21 to 23), until other Portuguese emigrants reported her to the police for not having a residence permit. She was imprisoned in Switzerland until she was sent back to Portugal, only to depart for the US via Canada some months later. She was able to cross the border into the US with help from a Portuguese family with whom she had been put in contact. Her crossing was facilitated by the fact that she had a baby daughter at the time. The Portuguese contact family in Canada was aware of this, and so (judging from the testimony of other Portuguese migrants who had made that crossing with much greater difficulties), she was not treated as badly as most. It is also worth mentioning that

comfortable in Portugal. These Portuguese shared socio-demographic characteristics with mainlanders. For more, see Castelo. 
in Portugal - before leaving for Switzerland - she had managed to complete high school and had attended a technical business school (escola comercial). This made her a (statistically speaking) rare case of a somewhat educated Portuguese woman, trying to get to the US.

Jo Santos wrote his autobiography as a kind of ethno-historical document in which he dedicates his life to preserving the values and material culture of the farmers of his birthplace, in remembrance of the rugged interior countryside of Mangualde. Apart from his autobiography, which he dictated to Soares, he gathered photographs and a collection of farm instruments and built a rural museum in his home village, Freixiosa. Jo Santos is now a successful businessman in the Newark area and a respected member of the Portuguese community, having received various awards and distinctions such as The Order of Merit in 1996 by the then acting Portuguese Prime Minister, António Guterres.

Like Felicidade Almeida, Tozé Silva speaks of his book as a life goal realized. His daughter, who was largely behind his decision to emigrate, encouraged him to write the book. Also from the rocky interior region of the country (Beiras), Tozé Silva did not have the opportunity to study as much as he had wanted and, like Jo Santos, only completed the fourth grade. Writing, even with grammatical errors, as he claims, represents living the dream for him, too. For Felicidade Almeida, publishing her book was the fulfilment of a desire: "Lembro-me do sonho de criança ser lindo, espectacular para mim, ao contrário do que a vida me ofereceu. Nem sempre a realidade se reflecte nos sonhos. Mas de sonho em sonho se constroem as vidas" (17). Over the years, Tozé Silva, like Felicidade Almeida, still regretted having to leave school so early. Felicidade Almeida never made it to the fourth grade: her teacher expelled her from school in the third grade, as she was absent too often helping her parents and siblings. Her mother's response to this was: "Não faz mal, já sabes ler e escrever, já sabes mais que eu; eu preciso de ti" (24). Her handwritten autobiography, given to her editor, João Martins, was an exercise in recovering the work of someone who had, like the great majority of Portuguese at the time, suffered from a poor education. It should be noted that on the eve of the transition to democracy in Portugal (1970) — decades after primary school for Felicidade Almeida — the illiteracy rate in Portugal was almost $40 \%$ for women and approximately $35 \%$ for men. For someone like Felicidade Almeida, writing her autobiography was not only a refutation of her poor schooling in 1940s Portugal but a bold statement 
that remains extremely rare for Portuguese women (and men) in diaspora communities. ${ }^{5}$ What, then, have these people actually done by writing their autobiographies?

\section{Texts and Contexts: Heuristic Value and Social Power of Self-Narratives}

Biographical and autobiographical narratives are central to the study of migration. Turning to the history of biographical studies within the social sciences, especially in the fields of sociology and anthropology, one sees the striking contemporaneity of studies interested in "biographical objects" (correspondence, life stories of immigrants, family pictures, etc.) and the social transformations happening at the time of their emergence. One may take as examples William Thomas and Florian Znaniecki's The Polish Peasant in Europe and America, by (1918-20) and Oscar Lewis's Children of Sánchez (1961), the latter an anlysis of the "cultures of poverty" in 1960s Mexico City. Thomas and Znaniecki worked with private correspondence and interviews with Polish immigrants in Chicago, while Lewis undertook a group inquiry within a Mexican family residing in the Tepito slum of Mexico City.

In the 1980s, the Italian sociologist Franco Ferrarotti became a reference point in biographical studies. His important contribution relies on the legitimation of the "biographical method" and the understanding of the heuristic potential of biography and its subjective and historical nature. Ferrarotti defended the ideographic (representational) value of biographical research, in opposition to the nomothetic (law-establishing) pretentions of positivistic sociology. By justifying the subjective and intersubjective character of social analysis, Ferrarotti helped qualitative sociologists to recognize the need to study human practices as processes that synthetize sometimes opposing, although complementary, elements: individuals and society, agency and structure. Validated subjectivity in the very work of researchers enables an understanding of life stories and biographical narratives in terms of their interpretations of the objective aspects of social life experienced by flesh and blood people. This understanding may extend into the field of migration studies to, for example, the

\footnotetext{
${ }^{5}$ There are few studies of Portuguese autobiographies written in diaspora communities. For more on this, see Lourenço.
} 
significance/feeling of living in a foreign country without a passport or valid documents, or what it is like for an immigrant to be discriminated against due to skin color, ethnic or religious background, and/or gender. These questions highlight the multi-dimensionality of biographical research in relation to its analytical supports or objects of study (that is, if they are oral, written, performative, material, or immaterial); the content of narratives (lived experiences, stories, plots and even possible lies and omissions); as well as the relational nature of biographical inquiry (subject positions, power relations, asymmetrical reciprocities in the field).

To understand the experiences of real people, we must take into account their narratives and lived experiences. For that, it is necessary for social analysts to interact with their interlocutors or gain access to written/oral biographical reports or other forms of expression and "biographical objects" (photography, film, performative acts, and artifacts). When listening to or reading the biographical reports effectively collected, the researcher is due to recognize her respective position or place as an interlocutor: her subject position in the interaction. Who tells, who asks, who listens? And the knowledge transmitted is one of experience, so the utterances produced and received provide an exceptional field for social analysis that is imminently relational and biopolitical. Reading and listening, like analytical study, are also interpretations that follow certain frameworks and world views. In our case, while reading the chosen autobiographies, there was a predisposition to see these works by Portuguese people living in Newark as local and glocal acts of empowerment that promote, or can promote, a revitalized, more positive image of the Portuguese emigrants within the public sphere in Portugal and the diasporic communities. This fact becomes more relevant in view of the vast, long-established Portuguese emigration, structurally sustained throughout history up to the present day (when emigration by Portuguese nationals is once again very high) and touching every continent in the world (Arroteia).

Biographical research serves this double purpose: on the one hand it allows for an understanding of the forms of experience and concrete interpretations of a narrator, on the other, it sheds light on the social and political meanings of these private experiences (biographical narratives) allowing for an attempt at a collective understanding of experience (research based on and into these narratives). According to Idalina Conde (45), the heuristic value of testimonies 
and biographical narratives for the social sciences depends on a guiding theory for each research case, alongside procedural theories. As more than a general theory of the subject - which is necessarily partial and problematic, yet applicable to each and every one of the studies of life histories - biographical research functions through contextualized theories of the subject: a theory of its subjects. The valuable contribution it can offer to social analysis, therefore, lies in the intense and more profound understanding of a given theme (and its multidimensionality), guided by a theoretical/practical objective clearly defined from the outset. This is the case with many anthropological studies of migration that use interviews and biographical accounts of migrants to understand transnational movements, transcontinental family dynamics, or post-colonial migrations (Glick-Schiller and Fouron). Literary studies also analyze autobiographical texts to discover and understand senses of belonging or cultural identity (cultural studies).

Biographical testimonies provide migration research with necessary information regarding the migratory experience of real individuals within a given migratory context (international, inter-regional, or transcontinental), while also (in)forming each narrator and respective listener or reader of the conditions for a possible discourse on their experiences. This is a discourse brought into the public sphere, which alone corresponds to real access to a certain power (Goody). In this sense, autobiographical texts become the empowerment of their narrators and eventual public, by simultaneously fostering awareness (and performativity) in relation to the writers and the collective dimension of their individual experiences. For example, the four biographies analyzed here portray a historical, sociological reality of emigration from continental Portugal to New Jersey over several decades. In this way, they fulfil the civic and political function of informing a less restricted (or even vast) and anonymous public of the history of two countries in different regions of the globe. The respective visions are necessarily partial, but the experience of each one is total (in Ferrarotti's sense).

It is significant that the four autobiographies at the center of the present article have come into existence via authors close to the heart of the Portuguese community in Newark. Although they began as or even remained manual laborers in the US, the authors all maintained personal, family, or professional relationships with clubs, associations or well-known businesses in the community. Jo Santos was president of the Portuguese Sports Club of Newark, 
and Tozé Silva is a member of ProVerbo, a cultural association belonging to the same club. Felicidade Almeida was the mother-in-law of a well-known Portuguese businessman, the owner of a chain of supermarkets and restaurants in Newark. Ilda Pinto de Almeida is a member of the Portuguese Instructive Social Club of Elizabeth, and the Portuguese Evangelical Igreja do Bom Pastor. It was through the church that she began to write and was encouraged to publish. This institutional and community support (even if only moral) reinforces the idea that authorship alone is not enough to ensure publication; the community is also needed as a base and as a means of lending authority to a writer. Fieldwork ethnography shows that more than "competency" is needed to speak of oneself: "authority" is also needed or, in other words, the capacity to be heard and recognized by the others (Fabre, Jamin, and Massenzio 10). This is beyond the reach of the great majority of people in the world, even in the digital era. In this context we can conclude that self-publishing is the first step towards accessing public competency and authority.

If the sociological profile of the four Portuguese autobiographies fits perfectly into the general pattern for Portuguese emigrants who arrived in the USA during the second half of the twentieth century, that they managed to publish their autobiographies is anything but typical. Several researchers have studied the continental (not Azorean) Portuguese community on the East Coast and its general characteristics as a culturally and linguistically distinct group in the North American mosaic (Pap; Onésimo Almeida; Holton and Klimt). Other authors are specifically interested in poetry written by the Portuguese in the USA (Capinha) and understand it as a semi-peripheral cultural production to guard against forgetfulness or complete domination by the "culture of the center." Graça Capinha sees this poetry produced by diaspora communities as the vanguard of Portuguese cultural resistance, since it is written in Portuguese in North America (Capinha). What seems most interesting and noteworthy here is the publication (even in unrevised or unedited editions) of autobiographies by the most improbable authors within the Portuguese panorama. These autobiographies are not only a symbolic contrast to the poor, rural and predemocratic Portugal of which the authors were a product and which they escape, but also translate into a kind of emancipation for the individual and his or her Portuguese community in the USA, since these were not noted for great literary production. They are historically associated, in fact, with low levels of formal 
education (Pap; Miguéis). The type of impact these four books will have on their readers today remains an open question to be addressed in further research, particularly because they are written in Portuguese. Such a fact poses a challenge to younger generations of Luso-descendants with higher levels of education who might not read Portuguese as well as they read English (Scott).

\section{Self-Writing: Themes of Life, Portraits of an Era}

All four autobiographies examined here begin by reflecting on the author's childhood, describing the village, family life, and region. All four authors were born in the center of Portugal, far away from large cities, in rural or fishing regions (Viseu, Mangualde, Murtosa). Ilda Pinto de Almeida alone was the daughter of a not-so-humble family of merchants with some education and little religious leaning, in contrast to the typical national scenario of the time as reflected in the backgrounds of the other authors. The four socio-historical life stories in these works paint a portrait of average people's lives, providing a window into the economic reality of Portugal from the first half of the twentieth century to the beginning of the 1960s. Emigration is a common thread in the timeline that can be traced from the birth of Felicidade Almeida (1929) to the birth of Ilda Pinto de Almeida (1961), respectively the oldest and the youngest in this small sample of authors.

The structural trend in Portuguese emigration over the centuries is well known, but the twentieth century was an unusually heavy period of regulated and unregulated emigration, namely to Brazil and France (Ferreira de Almeida; Antunes, "Vinte anos" and A emigração portuguesa). In this context, it should also be noted that Portuguese emigration to France in the 1960s and 1970s was the largest flow of illegal migration in the history of twentieth-century Europe, making Paris the world's second largest Portuguese city in demographic terms (Volovitch-Tavares, "Les phases"; Marta Silva). In fact, today there are still more Portuguese in Paris than in Porto.

We are now also witnessing a significant (and worrisome) new exodus of Portuguese: the figures for 2012 and 2013 are in fact even higher than those for 
$1960 .{ }^{6}$ But the sociological profile of these recent emigrants is different from those who left throughout the twentieth century, since they do have higher levels of education, even if the majority are still not part of the skilled work force (Peixoto). In this regard, Fernando Santos reminds us that a growing part of the present Portuguese emigration has a higher level of formal educational due to changes in minimum obligatory education in Portugal, established by the new educational system in the 1980s (ninth grade being the new minimum, compared to the previous expectation of fourth grade). "In 2011," writes Santos “. . . among the 557,000 unemployed people registered at the Portuguese Employment and Professional Training Institute, about 50,200 had a university degree-33,400 women and 16,800 men" (155). Even though the great majority of the new emigrants $(89 \%)$ are not holders of university degrees, there is nonetheless a higher percentage of college graduates today than during the pre-democratic period of emigration.

To be clear, the four authors at the center of the present article decided to leave the authoritarian, rural, poorly-educated and poverty-stricken Portugal that was then grappling with a colonial war in Africa. Childhoods marked by hunger, scarcity, various forms of violence and interrupted schooling lay behind their desire to leave their villages. In this regard, Felicidade Almeida writes:

[Eu sou] a primeira de sete irmãos e irmãs, filhos de pais muito pobres, trabalhadores e honestos. Lembro-me dos meus pais viverem num palheiro feito de tábuas, com dois quartos, sem ter soalho de madeira; o chão era de areia, com esteiras por cima, esteiras feitas de bambu, uma espécie de cana miúda para nos sentarmos. As camas eram umas tarimbas feitas de madeira, os colchões feitos de canas de milho secas. Havia ratos [...] Costumava ir no barco com os meus pais apanhar moliço. [...] Eu queria ir para a escola a minha mãe é que não me deixava ir. [...] Com doze anitos fazia uns recados para uma senhora e pagavam-me. Aos dezoito anos arranjei para ir trabalhar para um casal com dois meninos. Quis sair de casa e fui para perto da casa onde a minha irmãzinha estava com a tia, e cujos maus tratos eu já conhecia.

\footnotetext{
${ }^{6}$ According to the Portuguese Institute of Statistics (INE), during the year 2012, 121,418 people emigrated from Portugal, exceeding the highest number ever registered in the country: 120,239 people in 1966 .
} 
'O que fez esta inocente para lhe bater assim?'"Felicidade asked the woman. "Porque lhe perguntei,ela mandou-me embora e odiou-me sempre". Her sister remained. (18-41)

For his part, Tozé Silva writes:

Currelos, minha terra natal, sofria com todas as agruras da Guerra quando eu nasci (1942). Havia recionamento imposto pela falta de alimentos, e a pobeza era muita. Nasci numa família humilde, bastante pobre, e dos nove filhos que minha mãe deu à luz, eu fui o penúltimo. Deus quis chamar a si o sétimo e o nono, quando ainda eram criancinhas. Os sete restantes sobreviveram e resistiram a todas as dificuldades de então. Os mais velhos cedo partiram à procura de melhores vidas, uns para Lisboa, outros para o Alentejo, eu, o pequerrucho, quedei-me junto a minha mãe. O meu pai labutava já há anos como manajeiro no Alentejo (...) preocupando-se mais com a mulher do alfaiate lá do monte, com quem se travou de amores. Aos seis anos de idade eu tinha de ajudar a minha mãe no campo, semear batatas, feijões, plantar cebolas, milho e outros cereais. 1949 foi a entrada na escola. Foi uma coisa maravilhosa. Sentia-me vaidoso quando era apontado pelo professor como exemplo perante os outros alunos. Aprender a ler e a escrever faziam-me um menino feliz. [...] Terminei a $4^{\text {a }}$ classe com distinção..., mais tarde fui escolhido para ir para o Porto estudar com uma bolsa de estudo. Foi um enorme orgulho para mim mas o ser de uma família pobre, e vivendo sozinho com a minha mãe, era muito complicado. Com essa pouca idade, mesmo assim, ela precisava que eu a ajudasse. A resposta da minha mãe foi um rotundo não. [...]Eu tinha de suportar a disciplina brutal da minha mãe. [...] Aos 17 anos embarquei rumo a Lisboa (1-30)

Tozé was accepted as a warehouse helper and eventually grew professionally inside the company.

Jo Santos, in Mangualde, lived a similar childhood planting fruits, vegetables, and taking care of the animals. He finished elementary school at 11 and started working in construction right after. He remembers: "...ainda me lembro das grandes dificuldades que os meus pais passavam paradar de comer a 9 filhos e muitas vezes sem quaisquer recursos para adquirir alimentos. 
Aguardavam o que a terra podia dar. Porém, as terras eram de arrendamento e havia anos em que chegavam a vender o fruto (maçãs) ainda em flôr, nas árvores. Quando o tempo era de geadas mais fortes e essa flôr caía, o que as árvores produziam nem sequer dava para pagar o aluguer dos terrenos"(38). In a taped interview in Newark, Jo Santos talks about the hunger that he and his siblings experienced: "Um dia eu estava com tanta fome que fui à dispensa buscar um chouriço. O meu pai sentiu o cheiro na minha boca e bateu-me."

The case of Ilda Pinto de Almeida was a little different given her upbringing in a more prosperous family. Unlike the others, her decision to leave the country resulted from the unexpected death of her parents in a car accident when she was only thirteen years old. She went to live with her remaining family and felt like a burden to her older brothers, who were married. So she finished high school, worked in a small inn, got married, and soon left for Switzerland; she remained there with her husband for three years on a six-month visa. Felicidade Almeida went to Lisbon to work as a criada in $1948 .^{7}$ Tozé Silva went to Mozambique as a soldier in 1964. Jo Santos went to France in 1965, where he arrived a salto. ${ }^{8}$ In different ways, these experiences in other countries and cultures awakened a desire to go to the USA, where each of them already had close or distant relations.

As the authors reveal, some journeys were easier than others, and some individuals, such as Ilda Pinto de Almeida, who had to cross the American border from Canada, arrived in less than ideal conditions. Ilda Pinto de Almeida speaks forcefully of the difficulties she faced, as does Felicidade Almeida; however, the two male authors do so to a lesser extent. The men refer to the difficulty of communicating in an unknown language, the cold winters and the hard, demanding nature of their work: "Foi muito difícil a minha adptação ao novo sistema de trabalho no ramo da construção civil na América. Era tão diferente daquilo que tinha aprendido em Portugal! E o maior problema era sem dúvida dominar a língua inglesa." (José Santos, Freixiosa 45]. Tozé Silva writes:

\footnotetext{
${ }^{7}$ For more on the social role of criadas in Portuguese society, see Brasão.

${ }^{8}$ A salto ("parachuting in"), refers to irregular migration. In Silva's case, as with many thers, it involved crossing the border on foot, paying smugglers, and showing a torn photo the other half of which would be in the possession of the individual appointed to take him to his destination. For more on this theme, see José Vieira's 2002 documentary film, "A Fotografia Rasgada.”
} 
"Aquele ano (1996) foi uma das maiores tempestades de neve aqui em Newark. Era lindo de ver mas o trabalho que deu a limpar era de mais" (102).

The men devote more of their writing to various successes, the things for which they achieved recognition, their vacations, involvement in associations, and their political contacts in Portugal and New Jersey. On the other hand, Felicidade Almeida includes valuable aspects of Portuguese family life in Newark, especially in terms of networks of solidarity or dependence and the traditional relations between men and women, godparents and godchildren, the upbringing of children, family management and women's work. Tozé Silva includes a story of divorce and liberation not found in the other books. He speaks often of his good fortune and writes a poem on the occasion of a birthday:

Sou uma pessoa com sorte, pois nunca perdi o norte.

A este lindo cantinho, Currelos de gente honrada, em meu coração é guardada.

Com muito, muito carinho.

Viste-me nascer um dia, e eu cheio de alegria, cresci, entre sonhos e enganos. Hoje, estou aqui a recordar, e com todos vós a festejar um ciclo de setenta anos. (145)

José Santos's testimony is equally celebratory but focuses in particular on his activities within the Newark community and the village where he was born, where he has built the rural museum. José Santos and Ilda Pinto de Almeida write in the third person, while Tozé Silva and Felicidade Almeida write in the first person.

Felicidade Almeida and Ilda Pinto de Almeida emerge as courageous mothers who experienced great pain but survived. At the end of her book, the latter writes: 
Quantas vezes nesta caminhada de espinhos e de tempestades essa menina se refugiava algures no meio de nada. Pensava, falava com alguém que ela chamava de invisível, seu único e verdadeiro amigo. Ela queria acreditar que havia uma razão, que para além do visível era preciso acreditar, era necessário sonhar, não havia lugar para desistir. Coragem para ela era saber esperar com esperança na certeza que todos os sonhos que sonhara eram possíveis de alcançar. Coragem era ainda lutar e persistir até ao dia que se tornassem em realidade. (70)

For her part, Felicidade Almeida writes:

Ainda vivo só. Continuo a tomar conta da minha vida até poder e Deus querer. Peço a Deus que me deixe partir como o meu querido pai. Desejo de todo o coração não dar problemas às minhas filhas e, se precisar, que me ajudem. Se tiver de ir viver com elas e precisar de alguém que tome conta de mim, que paguem do que eu tenho: tenho a minha pensão, tenho os meus benefícios, tenho a minha casa. Não me deixem estar só quando eu mais precisar. Estamos todos de férias nesta vida, mas são muito curtas e então é saber escolher entre as rosas e os espinhos. (196)

The theme of thorns and hope is repeated in the writing of the two women; determination and action in that of the men. José Santos is well honored in his book by the ex-mayor of Mangualde who wrote the preface, and Tozé Silva by his relatives and friends, with whom he finished writing his story on his seventieth birthday.

The four writers who serve as the focus of the present article had the courage to make things known that not everyone would have had the strength to reveal. Portuguese diaspora communities are often portrayed as having little solidarity or respect for ordinary people. Perhaps the courage of these authors will inspire other compatriots who have many stories to tell. Overall, the books give public visibility to those who are still not viewed sympathetically either in Portugal or in diaspora communities: Portuguese working men and women technically described as emigrants/immigrants in both countries.

\section{Works Cited}


Almeida, Felicidade. Quando toda a esperança é azul. Newark: n.p., 2009. Print. Almeida, Ilda Pinto de. Quando o sol deixa de brilhar. Lisbon: Sinapis, 2014. Print.

Almeida, Onésimo. O Peso do Hífen. Ensaios sobre a experiência lusoamericana. Lisboa, ICS, 2010. Print

Antunes, M. L. Martinho. "Vinte anos de emigração portuguesa: alguns dados e comentários." Análise Social 8.31 (1970): 299-385. Print.

—. A emigração portuguesa desde 1950: dados e comentários. Lisbon: ISE/GIS, 1973. Print.

Arroteia, Jorge. A emigração portuguesa—suas origens e distribuição. Lisbon: Instituto de Cultura e Língua Portuguesa, 1983. Print.

Bahbha, Homi. "The World and the Home." Social Text 31-32 (1992): 141-53. Print.

Bauman, Zygmunt. Globalization: The Human Consequences. New York, Columbia UP, 1998. Print.

Brasão, Inês. O Tempo das Criadas. A condição servil em Portugal (1940-1970). Lisbon: Tinta da China, 2012. Print.

Brettell, Caroline. Anthropology and Migration: Essays on Transnationalism, Ethnicity and Identity. Walnut Creek, CA: Alta Mira, 2003. Print.

Browder, Laura. Slippery Characters: Ethnic Impersonators and American Identities. Chapel Hill, NC: U of North Carolina P, 2000. Print.

Capinha, Graça. "A produção poética na semiperiferia: a condição da bruma." Coimbra: CES, 1988. Print.

Castelo, Cláudia. O Modo Português de Estar no Mundo. O Luso-Tropicalismo e a Ideologia Colonial Portuguesa (1933-1961). Porto: Afrontamento, 1998. Print.

Cattarulla, Camila. Di próprio pugno: autobiografie di emigrante italiani in Argentina e in Brasile. Reggio Emilia: Diabasis, 2003. Print.

Cole, Sally. Women of the Praia: Work and Lives in a Portuguese Coastal Community. Princeton, Princeton UP, 1991. Print.

Conde, Idalina. "Problemas e virtudes na defesa da biografia." Sociologia Problemas e Práticas 13 (1993): 39-57. Print.

Fabre, Daniel, Jean Jamin, and M. Massenzio. "Jeu et enjeu ethnographiques de la biographie.” L'Homme 195-96 (2010): 7-21. Print. 
Fagundes, Francisco. "Portuguese Immigrant Experience in America in Autobiography." Hispania 88. 4 (2005) : 701-12. Print.

Feldman-Bianco, Bela, and Graça Capinha, eds. Identidades: estudos de cultura e poder. São Paulo: Huitec, 2000. Print.

Feldman-Bianco, Bela. "Multiple Layers of Time and Space: The Construction of Class, Ethnicity, and Nationalism among Portuguese Immigrants." Towards a Transnational Perspective on Migration: Race, Class, Ethnicity and Nationalism Reconsidered. Ed. Nina Glick-Schiller, et al. New York: New York Academy of Sciences, 1992. 145-74. Print.

Ferrarotti, Franco. "On the Autonomy of the Biographical Method." Biography and Society: The Life History Approach in the Social Sciences. Ed. D. Bertaux. London: Sage, 1983. Print.

Ferreira de Almeida, J. C. "A emigração portuguesa para França em 1953-65: alguns aspectos quantitativos." Análise Social 2.7-8 (1964) : 599-622. Print.

Foucault, Michel. "Les techniques de soi." Dits et écrits, 1954-1988, volume 2: 1976-1988. Paris: Gallimard, 1988. 1602-32. Print.

Glick-Schiller, Nina, and Georges Eugene Fouron. Georges Woke up Laughing: Long-distance Nationalism and the Search for Home. Durham, NC: Duke UP, 2001. Print.

Goody, Jack. The Power of the Written Tradition. Washignton, DC: Smithsonian Institution P, 2000. Print.

Holton, Kimberly DaCosta. "Pride, Prejudice and Politics: Performing Portuguese Folklore amid Newark's Urban Renaissance." Revista Etnográfica 9.1 (2005): 81-101. Print.

-, and Andrea Klimt. Community, Culture and the Makings of Identity: Portuguese-Americans along the Eastern Seabord. Dartmouth, MA: U of Massachusetts P, 2009. Print.

Instituto Nacional de Estatística. "Demographic Statistics, 2012.” 2013. Web. 11 Aug. 2104.

Koven, Michèle. "Speaking French in Portugal: An Analysis of Contested Models of Emigrant Personhood in Narratives about Return Migration and Language Use.” Journal of Sociolinguistics 17.3 (2013): 324-54. Print.

Lechner, Elsa. Enfants de l'eau: la reconstruction de l'identité en situation d'immigration, le cas des transmontanos en région parisienne. Saarbrücken: PU Européennes, 2010. Print. 
—. "Migração, pesquisa biográfica e emancipação social: contributos para a análise dos impactos da pesquisa biográfica junto de migrantes." Revista Crítica de Ciências Sociais 85 (2009): 43-64. Print.

—. "'Para deixar rasto na geografia onde passam os meus passos': Biografia e Transmissão na Diáspora Portuguesa em França." A Construção da Nação e Associativismo na Emigração Portuguesa. Ed. Daniel Melo and Eduardo Caetano da Silva. Lisbon: ICS, 2010. 179-92. Print.

- "Subjectivity, Displacement and the Ethics of Ethnographic Representation." Seeking the Self, Encountering the Other: Diasporic Narrative and the Ethics of Ethnographic Representation. Ed. Thuomas Hutunen, et al. Cambridge: Cambridge Scholars, 2008. 333-48. Print.

Lee, Robert, ed. First Person Singular: Studies in American Autobiography. New York: Vision, 1988. Print.

Lejeune, Phillippe. On Autobiography. Minneapolis: U of Minnesota P, 1989. Print.

Lewis, Oscar. The Children of Sánchez: Autobiography of a Mexican Family. New York: Vintage, 2011. Print.

Lourenço, Clara Moura. “Testemunhos autobiográficos de mulheres emigrantes: para uma nova gramática da portugalidade." e-cadernos CES 2 (2008). Web. 10 Aug. 2014.

Medeiros, Paulo de, and Sonja Herpoel. "Iberian Autobiography." Bulletin of Hispanic Studies 85.2 (2008): 163-66. Print.

Miguéis, José Rodrigues. Gente de Terceira Classe. Lisbon: Estampa, 1983. Print.

Pap, Leo. The Portuguese in the United States: A Bibliography. New York: Center for Migration Studies, 1976. Print.

Peixoto, João. "A emigração portuguesa hoje: o que sabemos e o que não sabemos." SOCIUS Working Papers 5 (2012). Web. 10 Aug. 2014.

Ricoeur, Paul. Temps et récit, tome III: Le temps raconté. Paris : Seuil, 1985. Print.

Robertson, Roland. Globalization: Social Theory and Global Culture. London: Sage, 1982. Print.

Santos, Fernando. Os Portugueses em New Jersey. Newark, NJ: n.p., 2014. Print.

Santos, José Abrantes dos, and Baldomiro Soares. Freixiosa. A minha terra e o museu. Newark and Loulé: n.p., 2013. Print. 
Scott, Dulce Maria. "The Education of Luso- Descendants: Theory, Data, and Recommendations." Direitos Humanos e Qualidade de Vida nas Comunidades Falantes de Português nos EUA e Canadá. Ponta Delgada: Governo dos Açores, 2012. 285-315. Print.

Silva, Marta. Os Trilhos da Emigração. Redes clandestinas de Penedono para França (1960-1974). Lisbon: Colibri, 2011. Print.

Silva, Tozé. Labirinto. Memórias de um beirão. Newark, NJ: n.p., 2012. Print.

Smith, Sidonie, and Julia Watson. Reading Autobiography: A Guide for Interpreting Life Narratives. Minneapolis: U of Minnesota P, 2010. Print.

Vieira, José, dir. A Fotografia Rasgada. 2002.

Villar, Carmen Ramos. "Janus and the Portuguese Emigrant: The Autobiographies of Portuguese Immigrants in the United States." LusoBrazilian Review 49.2 (2012): 232-50. Print.

Volovitch-Tavares, Marie-Christine. Portugais à Champigny, le temps des baraques. Paris: Autrement, 1995. Print.

-. "Les phases de l'immigration portugaise, des années vingt aux années soixante-dix." Actes de l'histoire de l'immigration. Mar. 2001. Web. 11 Aug. 2014.

Znaniecki, Florian, and William I. Thomas. The Polish Peasant in Europe and America. Boston : Gorham, 1918-20. Print. 